Eur J Clin Chem Clin Biochem

1995; 33:893-901

(ㄷ) 1995 Walter de Gruyter \& Co.

Berlin - New York

\title{
Excretion Pattern of Faecal Coproporphyrin Isomers I-IV in Human Porphyrias ${ }^{1}$ )
}

\author{
By Karl Jacob ${ }^{1}$ and Manfred O. Doss ${ }^{2}$ \\ 1 Institut für Klinische Chemie am Klinikum Großhadern der Universität München, München, Germany \\ ${ }^{2}$ Abteilung Klinische Biochemie, Fachbereich Humanmedizin, Philipps-Universität Marburg, Marburg, Germany
}

(Received June 7/August 17, 1995)

Summary: The relative proportions of the four coproporphyrin isomers I-IV were analysed in faeces of 20 healthy subjects and 60 patients suffering from one of the seven common types of hepatic or erythropoietic hereditary porphyrias. A newly developed, reliable method for sample preparation was applied, using reversed-phase thinlayer chromatography for the isolation of naturally occurring coproporphyrin free carboxylic acids. Accurate separation and quantitation of the individual isomers I-IV were achieved with the help of ion-pair high-performance liquid chromatography. The four coproporphyrin isomers I-IV were positively identified by on-line scanning of their fluorescence spectra in the emission and excitation modes. Recovery rates with this new analytical procedure were between 90 and $100 \%$, and coefficients of variation varied between 0.8 and $5.7 \%(\mathrm{~N}=7)$.

Diagnostically important findings were greatly increased proportions of isomer I and decreased proportions of isomers III, II and IV in erythropoietic porphyrias, such as congenital erythropoietic porphyria and protoporphyria. Significantly increased proportions of isomers III, II and IV, on the other hand, were observed in acute hepatic porphyrias, e. g. acute intermittent porphyria and porphobilinogen synthase deficiency porphyria, as compared with porphyria cutanea tarda ( $p<0.005$ and $p<0.03$, respectively).

Inversion of the faecal coproporphyrin III to I ratios and markedly elevated percentages of the atypical isomers II and IV were important diagnostic markers for variegate porphyria and hereditary coproporphyria. The highest proportions of isomer III were found in hereditary coproporphyria, where the amount of the isomers II and IV exceeded that of isomer I. Asymptomatic carriers of the relevant gene defect in families with hereditary coproporphyria could be detected by an increased faecal coproporphyrin III to I ratio.

Our results clearly demonstrate the potential of faecal coproporphyrin I-IV isomer ratios for the diagnosis and differential diagnosis of hereditary porphyrias.

\section{Introduction}

The porphyrias arise from inherited or acquired disorders of enzymes in the haem biosynthetic pathway, resulting in excessive production of porphyrins or porphyrin precursors (1).

\footnotetext{
1) Presented in part at the "International Symposium on Porphyrias and Heme Related Disorders", June 28-July 2, 1995, Helsinki, Finland.
}

Routes of elimination of different porphyrins mainly depend on the polarity of their molecular structure. The highly polar uroporphyrin, carrying eight carboxyl groups, is predominantly found in urine, whereas the apolar protoporphyrin is excreted exclusively via bile and faeces. The medium polarity of coproporphyrin results in excretion by both renal and hepatobiliary routes. 
The diagnosis of porphyrias is based on the analysis of porphyrins and porphyrin precursors in clinical materials, e. g., urine, faeces and blood $(1,2)$. Measurement of faecal porphyrins is particularly helpful for diagnosing the different acute hepatic porphyrias: acute intermittent porphyria, variegate porphyria, hereditary coproporphyria and porphobilinogen synthase deficiency porphyria. Increased faecal porphyrin excretion is also observed in chronic porphyrias, such as congenital erythropoietic porphyria, porphyria cutanea tarda and protoporphyria. The determination of porphyrin isomer ratios provides additional information for the differential diagnosis of porphyrias, especially when the ratio of coproporphyrin isomers I and III is altered $(3,4)$. Finally, the analysis of haem biosynthetic enzyme activities allows the identification of the causative enzyme deficiency in patients and often also in asymptomatic family members carrying the defective gene (1).

In a recent study, we analysed the relative proportions of the four coproporphyrin isomers I-IV in urine of patients suffering from the common types of hereditary porphyria (4). We observed significantly increased proportions of coproporphyrin III in acute hepatic porphyrias as compared with chronic hepatic porphyrias. In contrast, the highest proportion of coproporphyrin I was found in congenital erythropoietic porphyria which results from a defect of uroporphyrinogen III cosynthase $^{2}$ ). The atypical coproporphyrin isomers II and IV were present in all types of porphyria investigated, but did not provide additional diagnostic information. Here, we report results of a subsequent study of the excretion of the four coproporphyrin isomers I-IV in faeces from patients with the common types of hereditary porphyrias. Application of a newly developed reversed-phase thin-layer chromatographic (TLC) method allowed a highly selective isolation of free faecal coproporphyrins I-IV, which were completely separated and quantitated by isocratic ion-pair high-performance liquid chromatography (HPLC) (5). Another aim of this study was to compare the results of faecal and urinary coproporphyrin isomer ratios in the corresponding types of porphyria, and to evaluate the diagnostic relevance of faecal coproporphyrin isomers I-IV.

\section{Materials and Methods}

\section{Patients}

Stool samples were analysed from 20 healthy subjects $(12$ males, 8 females, 21 to 49 years old) and 60 patients suffering from the

\footnotetext{
2) Enzymes

Coproporphyrinogen oxidase (EC 1.3.3.3)

Porphobilinogen synthase (EC 4.2.1.24)

Protoporphyrinogen oxidase (EC 1.3.3.4)

Uroporphyrinogen III cosynthase (EC 4.2.1.75)
}

following types of porphyria: congenital erythropoietic porphyria $(N=6)$, erythrohepatic protoporphyria $(N=7)$, porphyria cutanea tarda $(N=13)$, acute intermittent porphyria $(N=15)$, porphobilinogen synthase deficiency porphyria $(\mathbb{N}=2)$, variegate porphyria $(N=7)$, hereditary coproporphyria $(N=10)$. Diagnosis of the respective porphyrias was based on biochemical measurements and characteristic clinical symptoms in manifest cases.

Table 1 shows the clinical status and faecal porphyrin excretion of seven selected patients with different types of hereditary porphyria.

\section{Stool samples}

Stool samples were protected from light, freeze-dried and kept frozen at $-20^{\circ} \mathrm{C}$ until analysis.

Analysis of faecal protoporphyrin and total coproporphyrins

Total coproporphyrins and protoporphyrin in faeces were determined by the high-performance thin-layer chromatographic method of Doss (7).

Sample preparation for determination of coproporphyrins I-IV

Faeces (10 to $100 \mathrm{mg}$, depending on the respective content of total coproporphyrins) were suspended in $2 \mathrm{ml} 9 \mathrm{~g} / \mathrm{l}$ aqueous $\mathrm{NaCl}$, oxi-

Tab. 1 Faecal porphyrins in seven patients with different types of porphyria.

\begin{tabular}{lll}
\hline Porphyria & $\begin{array}{l}\text { Total } \\
\text { coproporphyrins } \\
\text { (nmol/g } \\
\text { dry weight) }\end{array}$ & $\begin{array}{l}\text { Proto- } \\
\text { porphyrin } \\
\text { (nmol/g } \\
\text { dry weight) }\end{array}$ \\
\hline $\begin{array}{l}\text { Congenital erythropoietic } \\
\text { porphyria, male, 24 years } \\
\text { old, cutaneous phase (fig. la) }\end{array}$ & 146 & 2566 \\
$\begin{array}{l}\text { Protoporphyria, male, 56 } \\
\text { years old, after liver trans- } \\
\text { plantation, mild photoderma- } \\
\text { tosis }\end{array}$ & 26 & 924 \\
$\begin{array}{l}\text { Porphyria cutanea tarda, } \\
\text { male, 53 years old, } \\
\text { non-acute phase }\end{array}$ & 17 & 43 \\
$\begin{array}{l}\text { Acute intermittent porphyria, } \\
\text { female, 41 years old, } \\
\text { non-acute phase }\end{array}$ & 12 & 41 \\
$\begin{array}{l}\text { Porphobilinogen synthase de- } \\
\text { ficiency porphyria, male, } 36 \\
\text { years old, non-acute phase }\end{array}$ & 12 & 27 \\
$\begin{array}{l}\text { Variegate porphyria, female, } \\
\text { 28 years old, non-acute } \\
\text { phase }\end{array}$ & 229 & 37 \\
$\begin{array}{l}\text { Hereditary coproporphyria, } \\
\text { female, 29 years old, acute } \\
\text { phase (fig. 1b) }\end{array}$ & 939 & 1180 \\
\hline $\begin{array}{l}\text { Controls, } \\
\text { upper reference limit (6) }\end{array}$ & & \\
\hline & 37 & \\
\hline
\end{tabular}


dized with an aqueous solution of $10 \mathrm{mg} \mathrm{I}_{2}$ and $20 \mathrm{mg} \mathrm{KI}$ for 10 min, and treated with $\mathrm{Na}_{2} \mathrm{~S}_{2} \mathrm{O}_{3}$ to eliminate surplus iodine. Porphyrins were extracted with $2 \mathrm{ml}$ of $1.5 \mathrm{~mol} / \mathrm{HCl} / \mathrm{methanol} /$ iso-propanol $(16+3+3$, by vol.) (8). After vortexing and centrifugation at $2500 \mathrm{~g}$ for $10 \mathrm{~min}, 5 \mathrm{ml} 1.2 \mathrm{~mol} / 1 \mathrm{H}_{3} \mathrm{PO}_{4}$ were added to the supernatant. The porphyrins were then adsorbed on $100 \mathrm{mg}$ LiChroprep RP-18 material (25-40 $\mu \mathrm{m}$, Merck, Darmstadt, Germany), washed with water and eluted with methanol/acetone $(1+1$, by vol.).

Free porphyrin carboxylic acids were separated on reversed-phase pre-coated TLC plates (RP-18F, $0.25 \mathrm{~mm}$ layer thickness, Merck) using $0.1 \mathrm{~mol} / \mathrm{l}$ ammonium acetate $(\mathrm{pH} 4.1) / 20 \mathrm{mmol} / \mathrm{l}$ tetrabutylammonium phosphate ( $\mathrm{pH} 7.2) /$ acetone/methanol $(35+15+60$ +20 , by vol.) as the mobile phase. Coproporphyrins ( $R_{F}$ value 0.18 ) were eluted with acetone, the solvent was removed and the residue dissolved in $200 \mu \mathrm{l} 50 \mathrm{mmol} / \mathrm{h}$ methanolic tetrabutylammonium phosphate (pH 7.2) prior to HPLC analysis.

\section{HPLC analysis}

Simultaneous separation of the four coproporphyrin isomers I-IV was performed by isocratic ion-pair HPLC on a $5 \mu \mathrm{m}$ LiChrosorb RP-18 column (Merck) using tetrabutylammonium phosphate as the ion-pairing reagent (5). The isomer proportions were calculated from peak area ratios.

\section{Scanning of fluorescence spectra}

Fluorescence spectra of the individual coproporphyrin isomers were recorded with a programmable HPLC fluorescence detector (model F-1080, Merck), using the stop-flow technique. A slit width of $10 \mathrm{~nm}$ was used. Emission spectra were scanned from 450 to $800 \mathrm{~nm}$ after excitation at $396 \mathrm{~nm}$ (Soret band). Excitation spectra were recorded from 250 to $600 \mathrm{~nm}$ with the emission wavelength fixed at $624 \mathrm{~nm}$.

\section{Results and Discussion}

\section{Sample preparation method}

The presence of coproporphyrinogens in human faeces was first demonstrated by Fischer \& Orth (9) in a case with congenital erythropoietic porphyria, and later by Watson et al. (10) in non-porphyric patients. Pudek et al. (11), however, were unable to detect porphyrinogens in a series of stool samples. We started our sample preparation method with an oxidation step in order to avoid any non-enzymatic isomerization of the acid-labile porphyrinogens $(12,13)$. Once porphyrins are formed, they are absolutely stable to further isomerization.

A combined extraction procedure including hydrochloric acid and methanol/iso-propanol as organic modifier was applied to remove chlorophyll derivatives present in faeces (14).

The naturally occurring coproporphyrin free carboxylic acids were isolated using a recently developed reversedphase ion-pair TLC method, published elsewhere (15). Direct TLC separation of faecal porphyrin free carboxylic acids is faster and has an increased overall recovery as compared with the previously used methyl ester method (16).

\section{HPLC analysis}

The four coproporphyrin isomers I-IV were completely separated by isocratic ion-pair HPLC as described previously (5). This highly selective isolation procedure provides clean chromatograms for faecal coproporphyrins, which were not affected by interfering substances (fig. 1a,b). Some minor extraneous peaks were observed only in stool samples from patients with chronic hepatic porphyria, e. g., porphyria cutanea tarda.

\section{Fluorescence spectra of coproporphyrin isomers I-IV}

Positive identification of the four coproporphyrin isomers I-IV was achieved by on-line recording of their emission and excitation fluorescence spectra in faeces from a patient with hereditary coproporphyria. All four coproporphyrins exhibited the same emission spectra with a strong band at $624 \mathrm{~nm}$ and a broad shoulder of low intensity at ca. $670 \mathrm{~nm}$ (fig. 2a). In addition, identical excitation spectra with a characteristic structure were observed (fig. 2b). The latter showed an intense Soret band at $396 \mathrm{~nm}$ and smaller bands at 500,536 and $570 \mathrm{~nm}$, respectively. These spectra are comparable to those of the corresponding absorption spectra. In previous studies, we confirmed the presence of all four coproporphyrin isomers in stool samples of healthy subjects by on-line diode-array recording of their absorption spectra (16).

The high sensitivity of fluorescence spectroscopy enabled us to scan complete spectra of as little as $1 \mathrm{ng}$ coproporphyrin on the column.

\section{Methodological criteria}

The recovery rates were determined by adding various amounts of the individual coproporphyrin isomers to four uniform stool samples containing $67.0 \%$ isomer $\mathrm{I}$, $30.5 \%$ isomer III, $0.7 \%$ isomer II and $1.8 \%$ isomer IV. The mean analytical recovery was $101 \pm 1 \%(\overline{\mathrm{x}} \pm$ S.D. $)$ for isomer I, $98 \pm 1 \%$ for isomer III, $90 \pm 8 \%$ for isomer II and $94 \pm 4 \%$ for isomer IV.

The precision of the method was checked by assaying seven times a normal stool sample with an isomeric composition similar to that given above. The resulting coefficients of variation for isomer I, isomer III, isomer II and isomer IV were $0.8 \%, 1.7 \%, 5.7 \%$ and $3.9 \%$, respectively. Obviously, the precision depends on the relative abundance of the corresponding isomer. 
Composition of faecal coproporphyrin isomers I-IV in control subjects and in various porphyrias

The isomeric composition of faecal coproporphyrins I-IV was determined in 20 control subjects and 60 patients suffering from the common types of hereditary porphyria (tab. 2). The ratios of coproporphyrin isomers III to I and the combined percentages of the atypical isomers II and IV in individual stool samples are presented in figs. 3 and 4 , respectively.

Coproporphyrins

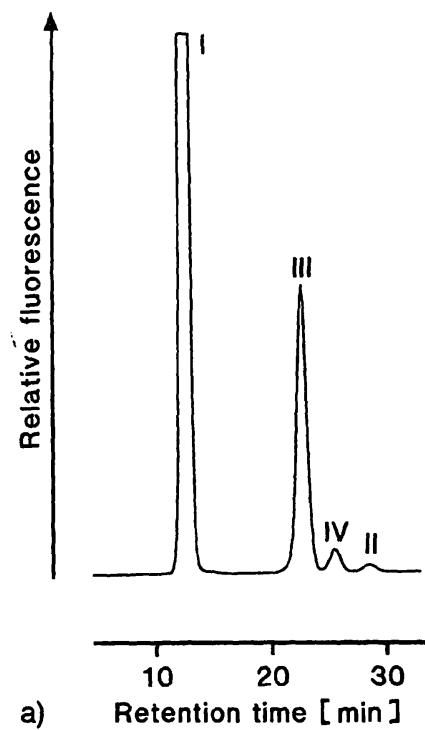

Fig. 1 HPLC separation of faecal coproporphyrin isomers I-IV (percentage of total coproporphyrins) from two patients with hereditary porphyria.

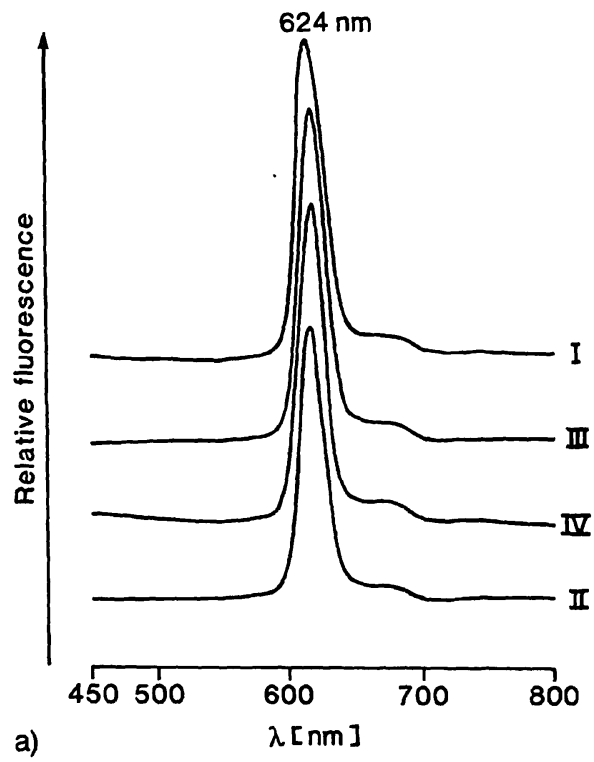

Fig. 2 a) Fluorescence emission spectra of the faecal coproporphyrins I-IV from a patient with hereditary coproporphyria (wavelength range $450-800 \mathrm{~nm}$, excitation at $396 \mathrm{~nm}$ ). The spectra are overlayed for comparison.
Coproporphyrin I was the predominant isomer in faeces of healthy controls (tab. 2, fig. 3), which agrees with earlier studies (17-19). High percentages of isomer I and decreased proportions of isomers II, III and IV were observed in erythropoietic porphyrias like congenital erythropoietic porphyria and protọporphyria (tab. 2, figs. 3 and 4).

A significantly higher ratio of coproporphyrin isomers III to I was found in acute hepatic porphyria, e.g. acute intermittent porphyria and porphobilinogen synthase ${ }^{2}$ )

\section{Coproporphyrins}

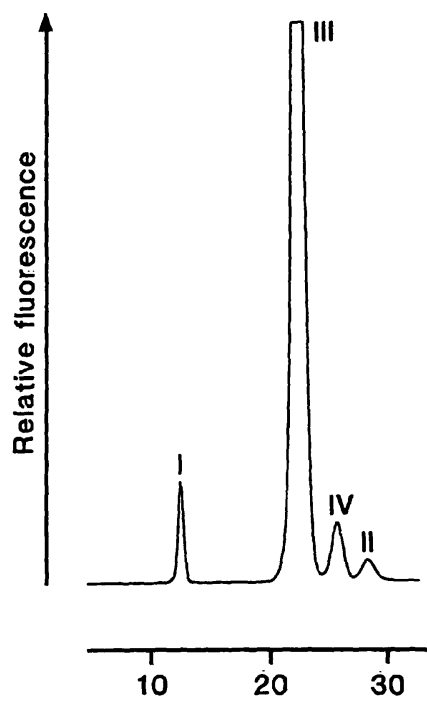

b) Retention time [ $\mathrm{min}]$

$\mathrm{a}=$ congenital erythropoietic porphyria, I (89.8), III (9.1), IV (0.8), II (0.3).

$\mathrm{b}=$ hereditary coproporphyria, I (4.0), III (88.8), IV (4.9), II (2.3).

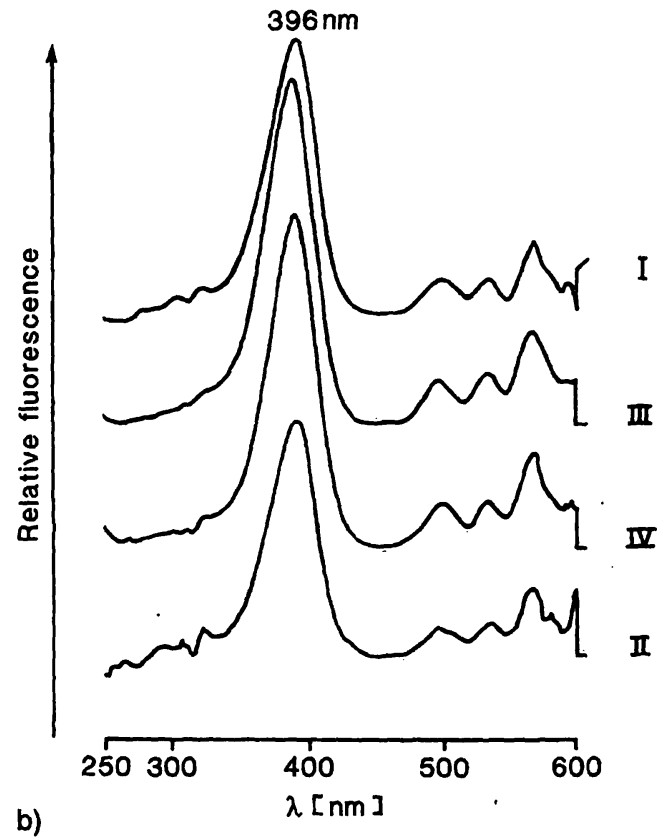

b) Fluorescence excitation spectra of the faecal coproporphyrins I-IV from the same patient as in fig. $2 a$ (wavelength range $250-$ $600 \mathrm{~nm}$, emission at $624 \mathrm{~nm}$ ). The spectra are overlayed for comparison. 
deficiency porphyria, in contrast to chronic hepatic porphyria like porphyria cutanea tarda $(p<0.005$, tab. 3$)$. In addition, the combined percentages of the atypical isomers II and IV were significantly higher in acute than in chronic hepatic porphyria $(p<0.03$, tab. 3$)$. In our study, the isomer III to I ratios of patients with acute intermittent porphyria exceeded slightly those reported by Minder (20).

Hereditary coproporphyria and variegate porphyria exhibited markedly elevated isomer III to I ratios (fig. 3), besides increased proportions of the atypical isomers II and IV (fig. 4). The predominance of faecal coproporphyrin III in hereditary coproporphyria and variegate porphyria has been reported by others $(20-23)$.

Atypical coproporphyrins II and IV were detected in each stool sample from both control subjects and porphyria patients; the relative content varied between 0.5 and $10.0 \%$ of total coproporphyrins. Surprisingly, the percentages of isomers II and IV were closely correlated with that of isomer III $(r=0.98)$, whereas a strong inverse correlation was observed in the case of isomer I $(r=-0.97)$.

\section{Pathobiogenesis of faecal coproporphyrin} isomers I-IV

Formation and excretion of faecal coproporphyrin isomers I-IV in porphyria patients are complex processes, which may be influenced by several factors, e. g. nature of the specific enzyme defect, excretion mode of the individual isomers by the liver cell, relative content of porphyrinogens, and possible contamination by porphyrins of bacterial (24) or dietary (25) origin.

Normally, an isomer ratio of $2: 1$ for coproporphyrins III and I is found in liver cells (17). The excretion rate of coproporphyrin I in bile is nearly twofold higher than that of isomer III (26). Approximately $90 \%$ of total coproporphyrin I is excreted in faeces due to the superior elimination capacity of bile (18), whereas isomer III is predominantly found in urine.

Porphyrinogens were detected by Logan et al. (27) in human bile in substantial amounts, varying between 2 and $32 \%$ of total porphyrins. Watson et al. (10) showed that coproporphyrinogens in bile and faeces account for 2 to $50 \%$ of total coproporphyrins.

Coproporphyrinogens can be isomerized in a post-hepatic, non-enzymatic and $\mathrm{pH}$-dependent process to form both the physiological isomers I and III, and the atypical isomers II and IV $(12,28)$. The isomerization is thermodynamically controlled, so that isomers II and IV are produced in an obligatory ratio of $1: 2$ (12), as confirmed in our study (tab. 2). The mechanism of this reaction includes opening of the porphyrinogen ring, formation of a spirocyclic intermediate, and subsequent rearrangement of one pyrrolic moiety $(29,30)$.

Tab. 2 Isomeric composition of faecal coproporphyrins I-IV (percentage of total coproporphyrins) in various porphyrias.

\begin{tabular}{|c|c|c|c|c|c|}
\hline \multirow[t]{2}{*}{ Porphyria } & \multirow[t]{2}{*}{$\mathrm{N}$} & \multicolumn{4}{|c|}{ Coproporphyrins* } \\
\hline & & I & III & II & IV \\
\hline Congenital erythropoietic porphyria & 6 & $\begin{array}{l}88.4 \pm 2.9 \\
(83-91)\end{array}$ & $\begin{array}{l}10.2 \pm 2.4 \\
(8-15)\end{array}$ & $\begin{array}{c}0.4 \pm 0.2 \\
(0.2-0.7)\end{array}$ & $\begin{array}{c}1.0 \pm 0.4 \\
(0.8-1.7)\end{array}$ \\
\hline Protoporphyria & 7 & $\begin{array}{l}77.6 \pm 8.4 \\
(66-88)\end{array}$ & $\begin{array}{l}21.1 \pm 8.3 \\
(12-34)\end{array}$ & $\begin{array}{c}0.3 \pm 0.1 \\
(0.1-0.5)\end{array}$ & $\begin{array}{l}1.0 \pm 0.5 \\
(0.4-1.8)\end{array}$ \\
\hline Porphyria cutanea tarda & 13 & $\begin{array}{l}73.5 \pm 10.2 \\
(48-85)\end{array}$ & $\begin{array}{l}24.4 \pm 9.9 \\
(13-51)\end{array}$ & $\begin{array}{c}0.7 \pm 0.4 \\
(0.3-2.0)\end{array}$ & $\begin{array}{l}1.4 \pm 0.7 \\
(0.7-2.9)\end{array}$ \\
\hline Acute intermittent porphyria & 15 & $\begin{array}{l}62.0 \pm 12.5 \\
(30-75)\end{array}$ & $\begin{array}{l}35.3 \pm 12.5 \\
(22-69)\end{array}$ & $\begin{array}{c}0.9 \pm 0.5 \\
(0.3-2.1)\end{array}$ & $\begin{array}{l}1.8 \pm 0.9 \\
(0.8-4.1)\end{array}$ \\
\hline $\begin{array}{l}\text { Porphobilinogen synthase deficiency } \\
\text { porphyria }\end{array}$ & 2 & $53.4 / 45.2$ & $44.2 / 51.5$ & $0.6 / 1.0$ & $1.8 / 2.3$ \\
\hline Variegate porphyria & 7 & $\begin{array}{l}19.7 \pm 8.6 \\
(11-32)\end{array}$ & $\begin{array}{l}74.5 \pm 7.9 \\
(63-84)\end{array}$ & $\begin{array}{l}1.8 \pm 0.5 \\
(1.3-2.7)\end{array}$ & $\begin{array}{l}4.0 \pm 0.8 \\
(3.2-5.4)\end{array}$ \\
\hline Hereditary coproporphyria & 10 & $\underset{(3-6)}{5.0 \pm 1.0}$ & $\begin{array}{l}87.1 \pm 2.0 \\
(84-91)\end{array}$ & $\begin{array}{c}2.4 \pm 0.5 \\
(1.7-3.1)\end{array}$ & $\begin{array}{l}5.5 \pm 1.1 \\
(3.8-6.9)\end{array}$ \\
\hline Controls & 20 & $\begin{array}{l}69.6 \pm 6.2 \\
(58-84)\end{array}$ & $\begin{array}{l}27.5 \pm 5.9 \\
(14-40)\end{array}$ & $\begin{array}{c}0.9 \pm 0.3 \\
(0.3-1.6)\end{array}$ & $\begin{array}{c}2.0 \pm 0.8 \\
(0.8-4.2)\end{array}$ \\
\hline
\end{tabular}

* mean value \pm S.D. (range) 
The elevated excretion of coproporphyrin I in faeces and urine of patients with congenital erythropoietic porphyria is due to the almost complete deficiency of uroporphyrinogen III cosynthase activity. Presence of coproporphyrinogen I in faeces of such patients (9) gives rise to the post-hepatic formation of the atypical isomers II and IV via non-enzymatic isomerization.

The increased proportion of coproporphyrin I in faeces of patients with protoporphyria corresponds to that in urine (4) and originates from hepatic involvement due to protoporphyrin accumulation (31). The content of biliary porphyrinogens in protoporphyria patients is very low (27), so that the formation of the atypical isomers II and IV is sharply reduced.

The faecal and urinary excretion of coproporphyrin III in patients with either acute intermittent porphyria or the extremely rare porphobilinogen synthase deficiency porphyria (32) is significantly higher as compared with that in porphyria cutanea tarda, resulting from a compensatory counterregulatory enhancement of porphyrinogen biosynthesis in the former conditions (32). The

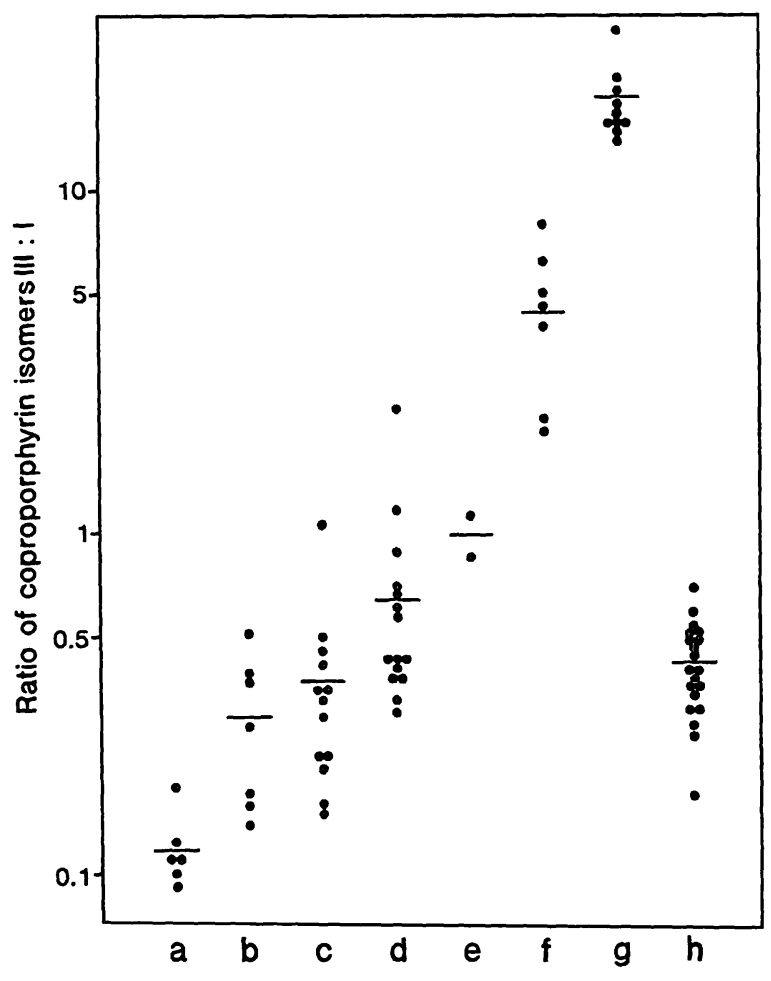

Fig. 3 Ratio of the faecal coproporphyrin isomers III to I in patients with various types of hereditary porphyria and in control subjects. Mean values are indicated by horizontal bars. Abbreviations:

$a=$ congenital erythropoietic porphyria,

$\mathrm{b}=$ protoporphyria,

c $=$ porphyria cutanea tarda

$\mathrm{d}=$ acute intermittent porphyria,

$\mathrm{e}=$ porphobilinogen synthase deficiency porphyria,

$\mathrm{f}=$ variegate porphyria,

$\mathrm{g}=$ hereditary coproporphyria,

$\mathrm{h}=$ control subjects. percentages of the atypical isomers II and IV are significantly higher in faeces of patients with acute hepatic porphyria as compared with those in chronic hepatic porphyria, probably due to a higher excretion of biliary and/or faecal porphyrinogens in acute hepatic porphyria.

In variegate porphyria, protoporphyrinogen and protoporphyrin are accumulated because of a deficiency of protoporphyrinogen oxidase ${ }^{2}$ ). The deficient penultimate step in haem biosynthesis impedes the normal metabo-

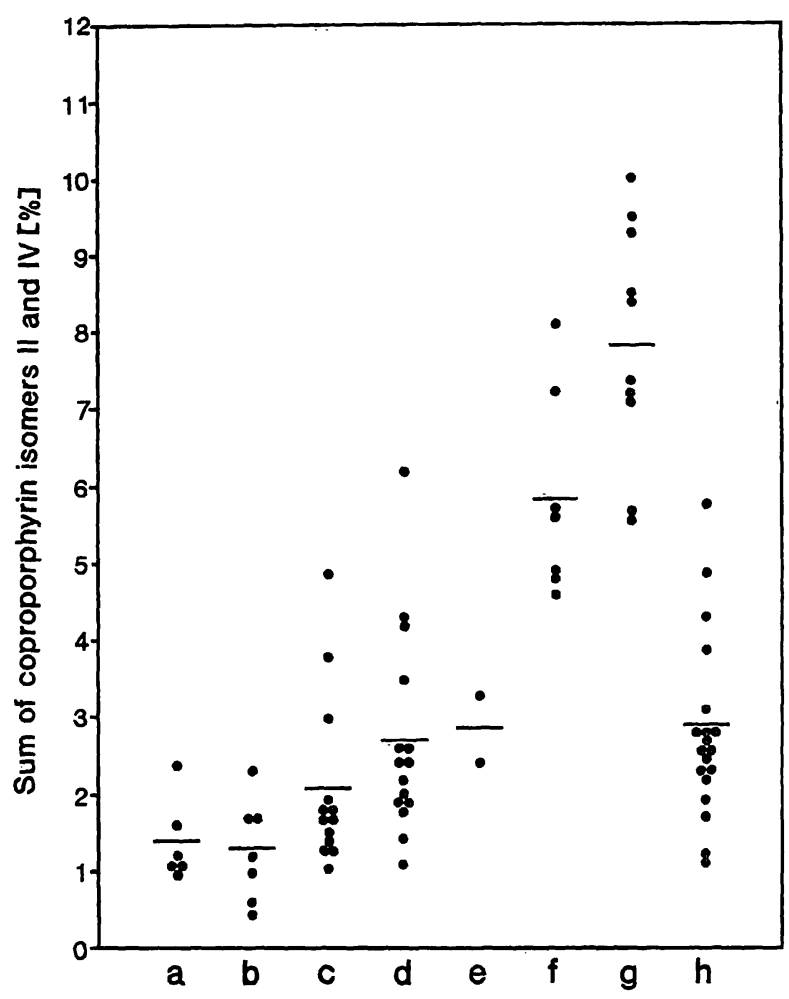

Fig. 4 Sum of the faecal coproporphyrin isomers II and IV (\%) in patients with various types of hereditary porphyria and in control subjects. Mean values are indicated by horizontal bars. Abbreviations as in fig. 3.

Tab. 3 Comparison of the isomeric composition of faecal coproporphyrins I-IV in acute and chronic hepatic porphyria.

\begin{tabular}{|c|c|c|c|}
\hline Porphyria & $\mathrm{N}$ & $\begin{array}{l}\text { Ratio of } \\
\text { copro- } \\
\text { porphyrin } \\
\text { III : I* }\end{array}$ & $\begin{array}{l}\text { Sum of } \\
\text { copro- } \\
\text { porphyrin } \\
\text { II + IV (\%)* }\end{array}$ \\
\hline \multicolumn{4}{|c|}{ Acute hepatic porphyria } \\
\hline $\begin{array}{l}\text { Acute intermittent } \\
\text { porphyria, } \\
\text { porphobilinogen } \\
\text { synthase deficiency } \\
\text { porphyria }\end{array}$ & 17 & $\begin{array}{l}0.70 \pm 0.49 \\
(0.30-2.31)\end{array}$ & $\begin{array}{l}2.8 \pm 1.2 \\
(1.1-6.2)\end{array}$ \\
\hline \multicolumn{4}{|c|}{ Chronic hepatic porphyria } \\
\hline \multirow{2}{*}{$\begin{array}{l}\text { Porphyria } \\
\text { cutanea tarda }\end{array}$} & 13 & $\begin{array}{l}0.36 \pm 0.23 \\
(0.15-1.06)\end{array}$ & $\begin{array}{l}2.1 \pm 1.1 \\
(1.0-4.9)\end{array}$ \\
\hline & & $\mathrm{p}<0.005$ & $p<0.03$ \\
\hline
\end{tabular}


lism of the intermediate coproporphyrinogen III, resulting in an increased excretion of coproporphyrin III in faeces (tab. 2, fig. 3) and urine (4). In addition, the relatively high content of porphyrinogens in the bile of such patients (ca. $26 \%$ of total porphyrins) (27) results in enhanced formation of the atypical isomers II and IV in faeces (tab. 2, fig. 4).

The highest proportions of coproporphyrins II, III and IV were found in faeces of patients suffering from hereditary coproporphyria, where deficient coproporphyrinogen oxidase activity is responsible for the largely raised excretion of isomer III in faeces (tab. 2, fig. 3) and urine (4). The markedly increased formation of the atypical isomers II and IV arises from non-enzymatic isomerization of the abundant coproporphyrinogen III.

\section{Excretion of faecal porphyrins other than coproporphyrin}

Polar porphyrins, e.g., uroporphyrin, hepta- and hexacarboxyporphyrin, are normally found in faeces only in trace amounts. Heptacarboxyporphyrin and especially isocoproporphyrin are characteristic porphyrins in faeces of patients with chronic hepatic porphyria and its cutaneous manifestation phase, porphyria cutanea tarda (1). A minimal increase of coproporphyrins in porphyria cutanea tarda is common in patients with excessive porphyrinuria, whereas faecal protoporphyrin is slightly elevated in cases with heavy alcohol consumption (33).

Increased faecal excretion of pentacarboxyporphyrin can be found in hereditary coproporphyria and variegate porphyria together with raised coproporphyrin III levels, resulting in a ratio of about $1: 10$ (34).

The lipophilic protoporphyrin is exclusively eliminated via bile and faeces, serving as the essential diagnostic finding in variegate porphyria (1). An additional rise in tricarboxyporphyrin and coproporphyrin III may occur simultaneously (35).

In harderoporphyria, the recessive variant of hereditary coproporphyria, a typical increase of the metabolite harderoporphyrin (tricarboxyporphyrin) is observed (1, 36).

Protoporphyria is characterized by greatly raised erythrocyte protoporphyrin concentration, causing a concomitant protoporphyrinaemia and increased biliary elimination of protoporphyrin. Hepatic involvement due to deposition of crystalline, hepatotoxic protoporphyrin occurs in about $25 \%$ of cases (31). Protoporphyrin-induced liver complications result in progressive cholestatic cirrhosis with a sharply diminished hepatobiliary excretion capacity for protoporphyrin. Consequently, the erythro- cyte protoporphyrin levels increase even further, which ultimately may require liver transplantation (37).

\section{Diagnostic relevance of faecal \\ coproporphyrin isomers I-IV}

Greatly increased proportions of faecal coproporphyrin I together with decreased proportions of isomers II, III and IV are typical findings in the biochemical diagnosis of congenital erythropoietic porphyria.

In protoporphyria and porphyria cutanea tarda, patterns of faecal coproporphyrins I-IV are similar and cannot be used to distinguish these two conditions. Although differences in coproporphyrin isomer ratios in porphyria cutanea tarda and acute intermittent porphyria as well as in porphobilinogen synthase deficiency porphyria are statistically significant (tab. 3), their diagnostic relevance is compromised by the overlap of ranges (figs. 3 and 4).

The isomer ratios of coproporphyrins III to I display an extraordinary increase in faeces from patients with variegate porphyria and especially in hereditary coproporphyria as compared with the other porphyrias (fig. 3 ). Due to the strong positive correlation between the physiological isomer III and the atypical isomers II and IV, the latter serve as additional diagnostic markers (fig. 4). For example, the percentage of coproporphyrin IV exceeds that of isomer I in faeces of patients with hereditary coproporphyria (fig. 1b). Variegate porphyria and hereditary coproporphyria can be clearly distinguished by comparing the respective excretion of faecal coproporphyrins and protoporphyrin (tab. 1) (1).

Analysis of faecal coproporphyrin isomers I-IV in a family with hereditary coproporphyria

The ratio of faecal coproporphyrin isomers III to I was used successfully for screening adult patients at risk of hereditary coproporphyria in a large family study by Blake et al. (22), and by Sieg \& Doss (38).

In our study, we analysed the total faecal coproporphyrins and the relative proportions of the isomers $I-I V$ in 6 members of a family with hereditary coproporphyria (tab. 4). The index patient of this family (daughter 1) presented with severe abdominal attacks. She excreted large amounts of faecal coproporphyrins with greatly raised proportions of the physiological isomer III besides the atypical isomers II and IV (tab. 4). Her father, her sister and her brother 2 excreted elevated amounts of faecal coproporphyrins, too, and nearly identical isomer ratios. Here, the combined determination of total faecal coproporphyrins and the isomeric composition of copro- 
Tab. 4 Composition of faecal coproporphyrin isomers I-IV in a family with hereditary coproporphyria.

\begin{tabular}{llll}
\hline Member of the family & $\begin{array}{l}\text { Total } \\
\text { coproporphyrins } \\
\text { (nmol/g dry weight) }\end{array}$ & $\begin{array}{l}\text { Ratio of } \\
\text { coproporphyrin III : I }\end{array}$ & $\begin{array}{l}\text { Sum of } \\
\text { coproporphyrin II + IV } \\
(\%)\end{array}$ \\
\hline Father & 530 & 14.0 & 5.6 \\
carrier
\end{tabular}

* Index patient

porphyrins I-IV designated them as carriers of the deficient coproporphyrinogen oxidase ${ }^{2}$ ) gene, although they were so far clinically asymptomatic. On the other hand, the mother and the brother 1 of the index patient showed normal excretion of total faecal coproporphyrins and a normal composition of the four coproporphyrin isomers, which makes the presence of a deficient coproporphyrinogen oxidase gene unlikely.

Thus, analysis of total faecal coproporphyrins, combined with the proportions of their isomers I-IV, provided a simple identification of affected members in this family with hereditary coproporphyria, and it confirmed previous findings with isomers I and III $(22,38)$. Analysis of urinary coproporphyrin isomers in the same subjects (data not shown) showed inadequate diagnostic sensitivity and did not allow identification of carriers of the genetic defect.

\section{Conclusion}

An improved sample preparation method enabled the reliable determination of the four coproporphyrin isomers I-IV in faeces of porphyria patients.

Greatly increased proportions of coproporphyrin I and decreased proportions of isomers III, II and IV are diagnostically relevant in erythropoietic porphyria, namely congenital erythropoietic porphyria and protoporphyria. Similar results can be obtained from the analysis of urine.

Although ratios of coproporphyrin isomers III to I, as well as the percentages of the atypical isomers II and IV, are significantly higher in acute hepatic porphyrias like acute intermittent porphyria and porphobilinogen synthase deficiency porphyria as compared with porphyria cutanea tarda, the diagnostic value of these findings is compromised by an overlap of ranges.

The mostly increased proportions of faecal coproporphyrins III, II and IV, together with markedly decreased proportions of isomer I, are found in variegate porphyria and especially in hereditary coproporphyria, providing a good diagnostic marker for these conditions.

In family studies, asymptomatic gene carriers for hereditary coproporphyria with normal faecal excretion of coproporphyrins can be detected by the inversion of their coproporphyrin III to I ratio. Individuals with latent phases of hereditary coproporphyria, characterized by a slight to moderate increase of faecal coproporphyrins (and urinary coproporphyrins too), are also diagnosed by the dominance of isomer III.

Thus, determination of the proportions of faecal coproporphyrin isomers I-IV offers valuable information for the diagnosis and differential diagnosis of porphyrias. The dynamic range of faecal coproporphyrin isomer ratios is more pronounced than that of urinary coproporphyrins; in addition, the atypical isomers II and IV contribute to the diagnostic importance of faecal coproporphyrins.

\section{Acknowledgements}

This work was supported by the Hans-Fischer-Gesellschaft (Munich, Germany). The skilful technical assistance of Mr. E. Egeler and Mr. B. Hennel (Munich) and Mrs. M. Wenz (Marburg) is gratefully acknowledged. We are indebted to Mrs. D. Nagel for the statistical analyses.

\section{References}

1. Doss MO, Sassa S. The porphyrias. In: Noe DA, Rock RC, editors. Laboratory medicine. The selection and interpretation

of clinical laboratory studies. Baltimore: Williams \& Wilkins, 1994:535-53. 
2. Elder GH, Smith SG, Smyth SJ. Laboratory investigation of the porphyrias. Ann Clin Biochem 1990; 27:395-412.

3. Doss M, Schermuly E. Urinary porphyrin excretion pattern and isomer distribution of $\mathrm{I}$ and $\mathrm{IIl}$ in human porphyrin disorders. In: Doss $\mathrm{M}$, editor. Porphyrins in human diseases. Basel: Karger, 1976:189-204.

4. Jacob K, Doss MO. Composition of urinary coproporphyrin isomers $\mathrm{I}-\mathrm{IV}$ in human porphyrias. Eur $\mathrm{J} \mathrm{Clin} \mathrm{Chem} \mathrm{Clin}$ Biochem 1993; 31:617-24.

5. Jacob K, Egeler E, Neumeier D, Knedel M. Isocratic ion-pair high-performance liquid chromatographic methods for the determination of uroporphyrin and coproporphyrin type II and IV isomers in human urine. J Chromatogr 1989; 468:329-38.

6. Doss $M$. Normal ranges of porphyrins and precursors in human tissue, urine and feces. In: Strik JJTWA, Koeman JH, editors. Chemical porphyria in man. Amsterdam: Elsevier, North-Holland Biomedical Press, 1979:221.

7. Doss MO. Porphyrins and porphyrin precursors. In: Curtius HC, Roth M, editors. Clinical biochemistry - principles and methods. Berlin, New York: Walter de Gruyter, 1974:132371 .

8. Jacob K, Egeler E, Hennel B, Luppa P, Neubrand MW. Determination of bile porphyrins by ion-pair high-performance liquid chromatography. Fresenius J Anal Chem 1992; 343:72-3.

9. Fischer $\mathrm{H}$, Orth $\mathrm{H}$. Die Chemie des Pyrrols, Vol. II (Pt 1). Leipzig: Akademische Verlagsgesellschaft, 1937:472.

10. Watson CJ, Pimenta de Mello R, Schwartz S, Hawkinson VE, Bossenmaier I. Porphyrin chromogens or precursors in urine, blood, bile, and feces. J Lab Clin Med 1951; 37:831-42.

11. Pudek MR, Schreiber WE, Jamani A. Quantitative fluorometric screening test for fecal porphyrins. Clin Chem 1991; 37:826-31.

12. Mauzerall $D$. The thermodynamic stability of porphyrinogens. J Amer Chem Soc 1960; 82:2601-5.

13. Jacob K, Egeler E, Hennel B, Luppa P. Coproporphyrin isomers II and IV are normal constituents of human urine. J Clin Chem Clin Biochem 1989; 27:659-61.

14. Lockwood WH, Poulos V, Rossi E, Curnow DH. Rapid procedure for fecal porphyrin assay. Clin Chem 1985; 31:1163-7.

15. Junker-Buchheit A, Jork $H$. Urinary porphyrins: ion-pair chromatography and fluorimetric detection. J Planar Chromatogr 1988; 1:214-9.

16. Jacob K, Egeler E, Hennel B, Neumeier D, Luppa P. Application of ion-pair high-performance liquid chromatography to detection of the atypical coproporphyrin isomers II and IV in human faeces. J Chromatogr 1991; 572:317-20.

17. Aziz MA, Watson CJ. An analysis of the porphyrins of normal and cirrhotic human liver and normal bile. Clin Chim Acta 1969; 26:525-31.

18. Doss $M$. Alkoholtoxische hepatische Porphyrinopathien. In: Zelder O, Fischer M, Eckert P, Bode JC, editors. Experimentelle und Klinische Hepatologie. Stuttgart, New York: Georg Thieme Verlag, 1980:260-7.

19. Rocchi E, Gibertini P, Santunione V, Balli F, Ventura E. Faecal and urinary coproporphyrin isomers in biliary atresia and neonatal hepatitis. Ric Clin Lab 1980; 10:501-9.

20. Minder EI. Coproporphyrin isomers in acute-intermittent porphyria. Scand J Clin Lab Invest 1993; 53:87-90.

21. Kappas A, Sassa S, Galbraith RA, Nordmann Y. The porphyrias. In: Scriver CR, Beaudet AL, Sly WS, Valle D, editors. The metabolic basis of inherited disease. New York: McGrawHill Book Company, 1989:1305-65.
22. Blake D, McManus J, Cronin V, Ratnaike S. Fecal coproporphyrin isomers in hereditary coproporphyria. Clin Chem 1992; 38:96-100.

23. Lim CK, Peters TJ. Urine and faecal porphyrin profiles by reversed-phase high-performance liquid chromatography in the porphyrias. Clin Chim Acta 1984; 139:55-63.

24. Beukeveld GJJ, Wolthers BG, van Saene JJM, de Haan THIJ, de Ruyter-Buitenhuis LW, van Saene RHF. Patterns of porphyrin excretion in feces as determined by liquid chromatography. Reference values and the effect of flora suppression. Clin Chem 1987; 33:2164-70.

25. Rose IS, Young GP, John DJBS, Deacon MC, Blake D, Hendcrson RW. Effect of ingestion of hemoproteins on fecal excretion of hemes and porphyrins. Clin Chem 1989; 35:2290-6.

26. Kaplowitz N, Javitt N, Kappas A. Coproporphyrin I and III excretion in bile and urine. J Clin Invest 1972; 51:2895-9.

27. Logan GM, Weimer MK, Ellefson M, Pierach CA, Bloomer JR. Bile porphyrin analysis in the evaluation of variegate porphyria. N Engl J Med 1991; 324:1408-11.

28. Jacob K, Egeler E, Hennel B, Luppa P, Neumeier D. The isomer ratios of urinary coproporphyrins I-IV are $\mathrm{pH}$-dependent. Eur J Clin Chem Clin Biochem 1991; 29:115-9.

29. Mathewson JH, Corwin AH. Biosynthesis of pyrrole pigments: a mechanism for porphobilinogen polymerization. J Amer Chem Soc 1961; 83:135-7.

30. Stark WM, Hart GJ, Battersby AR. Synthetic studies on the proposed spiro intermediate for biosynthesis of the natural porphyrins: inhibition of cosynthetase. J Chem Soc, Chem Commun 1986:465-7.

31. Doss MO, Frank M. Hepatobiliary implications and complications in protoporphyria, a 20-year study. Clin Biochem 1989; 22:223-9.

32. Doss $M$, von Tiepermann $R$, Schneider J, Schmid H. New type of hepatic porphyria with porphobilinogen synthase defect and intermittent acute clinical manifestation. Klin Wochenschr 1979; 57:1123-7.

33. Doss MO. Alcohol and porphyrin metabolism. In: Seitz HK, Kommerell B, editors. Alcohol related diseases in gastroenterology. Berlin, Heidelberg: Springer Verlag, 1985:232-52.

34. Doss M, von Tiepermann R, Verspohl F. Hereditäre Koproporphyrie in der Bundesrepublik Deutschland. J Clin Chem Clin Biochem 1978; 16:519-24.

35. Doss MO, von Tiepermann R. Biochemical and clinical transitions between the hereditary hepatic porphyrias. New concepts. In: Doss MO, editor. Diagnosis and therapy of porphyrias and lead intoxication. Berlin, Heidelberg, New York: Springer Verlag, 1978:29-45.

36. Doss $M$, von Tiepermann $R$, Köpp W. Harderoporphyrin coproporphyria. Lancet 1984; 1:292.

37. Doss MO, Frank M, Sieg 1. Cholestatische erythrohepatische Protoporphyrie: Porphyrinstoffwechsel vor und nach Lebertransplantation. Z Gastroenterol 1993; 31 (2 Suppl):85-9.

38. Sieg I, Doss MO. HPLC der Koproporphyrin-I/III-Isomere bei hepatischen Porphyrinopathien. Lab Med 1992; 16:89-96.

Prof. Dr. K. Jacob

Institut für Klinische Chemie am

Klinikum Großhadern der

Universität München

Marchioninistraße 15

D-81366 München

Germany 
